UDC 332.33:332.2.021.8

DOI: 10.31651/2076-5843-2019-4-14-25
ZOS-KIOR Mykola

Dr. Sc. (Ekon), Associate Professor, Professor the Department of Management, Poltava State Agrarian Academy, Poltava, Ukraine

ORCID ID: https://orcid.org/0000-0001-8330-2909 zoskior@gmail.com

\section{OVCHARENKO Ievgen}

Dr. Sc. (Ekon), Professor, Head of Department of Public Administration, Management and Marketing, Volodymyr Dahl East Ukrainian National University, Severodonetsk, Ukraine ORCID ID: https://orcid.org/0000-0001-5267-5067 evvoukr@gmail.com

\section{ARBUZOVA Tetyana}

$\mathrm{PhD}$ in economics, Associate Professor, Associate Professor of Department of Public Management, Administration and International Economics, Bilotserkiv National Agrarian University Bila Tserkva, Ukraine ORCID ID: https://orcid.org/0000-0001-7806-8249 tv_arbuzova@ukr.net

\title{
SUSTAINABLE DEVELOPMENT, DECENTRALIZATION AND HARMONIZATION IN THE LAND MANAGEMENT OF AGRARIAN SECTOR
}

Within the framework of sustainable development of rural territories, decentralization and harmonization, the European standards have first considered the possibilities of land management. The basic world tendencies and their influence on the land resources management of the agrarian sector of the Ukrainian economy are determined. The laws of national land use and the problems they cause are considered. Taking into account tendencies and revealed patterns, modern forecasts of agrarian business development and consequences of their realization in land management in Ukraine were determined. The author offers a scheme of "domino effect" from the implementation of investment processes in agriculture to the harmonization of land management with European standards. It is proposed to create a network structure of organic products under the TM "UkrWay" on the analytical and consulting platform of the Association "Ukrainian Agrarian Business Club", which allows you to quickly diagnose demand at the expense of the consumer as a quasi-employee, quasi-observer and quasi-marketer, and accordingly apply dynamic systems land resources of the agricultural sector of the economy. A scheme of harmonization of economic interests of land management entities under decentralization conditions through their financial and organizational capabilities has been developed to focus on ownership, management and use of management objects.

Keywords: agrarian sector, sustainable development, harmonize, land management, decentralization.

Introduction. The study of forecasts for the economic, social, environmental and integrated efficiency of land management (here in after LM) of agricultural sector allow a formalized transition to the advanced world models of land-use. The state should operate with available tools, taking into consideration not only the economic laws, but also the trends and patterns that have been established at the level of world agricultural relations, including land relations. Evolution of 
processes with limited predictability requires a particular purpose and context that implies the harmonization of LM efficiency in domestic agricultural sector with globalization prospects.

Literature review. This context makes the logic of this study. As for the major world trends in the development of the agricultural sector, they are reduced to a significant increase in demand for agricultural products and foodstuffs with increasing volatility in their prices (Table 1).

Table 1

Major global trends and their impact on land management in the agricultural sector in Ukraine*

\begin{tabular}{|l|l|}
\hline \multicolumn{1}{|c|}{ Global trends } & \multicolumn{1}{c|}{ Consequences for Ukraine } \\
\hline $\begin{array}{l}\text { Significant growth in demand for agricultural } \\
\text { products and food, especially for beef, pork, poultry, } \\
\text { butter, cheese, powdered whole milk and skim milk }\end{array}$ & $\begin{array}{l}\text { Increase in revenue from all national agents of land } \\
\text { interests. } \\
\text { A significant increase in domestic prices for } \\
\text { agricultural products and foodstuffs }\end{array}$ \\
\hline Volatility of world prices & $\begin{array}{l}\text { Farmers } \\
\text { agricultural insurance }\end{array}$ \\
\hline $\begin{array}{l}\text { The rate of production of agricultural raw materials } \\
\text { outpacethe growth of their processing and storage }\end{array}$ & $\begin{array}{l}\text { Shortfall in received added value for agents of land } \\
\text { interests }\end{array}$ \\
\hline The global problem of food production & $\begin{array}{l}\text { Growth of land prices, the intensification of } \\
\text { production }\end{array}$ \\
\hline $\begin{array}{l}\text { Conclusion of free trade agreements within the } \\
\text { Transatlantic partnership in trade and investment } \\
\text { between the US and the EU (TTIP) }\end{array}$ & $\begin{array}{l}\text { Diversification of production, harmonization of } \\
\text { national standardization and certification system } \\
\text { with the world standards }\end{array}$ \\
\hline
\end{tabular}

*Source: Systematized according to the materials [2, p. 13; 5].

These facts, on the one hand, lead to an increase in revenues of the national agents of land interests, and on the other hand (according to the effect of exports) to the growth of domestic prices for agricultural products and foodstuffs to the world level. At the same time, the limited range of exports is a negative factor for Ukraine whose agribusiness entities perceive volatility of world prices at the level of financial losses.

The way out of this situation could be to increase the range of agricultural and food products, expanding sales lines as well as circles of partner countries. The rate of production of agricultural raw materials outpace the growth of their processing and storage, therefore national agents of land interests receive less added value, as global competition is more significant at the market of finished products and warehouse logistics.

Against the background of the global problem of food production, in addition to increasing demand for production, the load on the land also increases because of the transition to biofuels. Among the most significant global trends, formation of a free trade zone between the US and the European Union (TTIR) should be highlighted; which will also influence significantly the agricultural market situation, and accordingly, through a number of globalization impacts on LM, the relationship between a number of agents of land interests will transform from competing into complementary model.

The trends mentioned above will be for Ukraine generally positive consequences, provided that the national preventive and administrative adapters develop, including the system of agricultural insurance $[1,10,13,14,16]$, and there are restrictions on acquisition of agricultural land by foreigners, harmonization of national standardization and certification system with the world.

It should be noted that these trends also reflect both regional (EU) and national trends, which, incidentally, almost coincide (due to the effects of global deformation): the increased proportion of gross agricultural output in GDP; increased area of a farm; increased percentage of employees; strengthened vertical integration; increased capital intensity of production as well.

The purpose of the article is to study sustainable development, decentralization and harmonization in the land management of agrarian sector.

Results and discussion. Besides the general trend, certain patterns of land use in the 
agricultural sector of Ukraine have recently been formed (Table 2), which are generally also coincide with the global situation. These patterns suggest many unresolved issues in land use, such as: targeted use of suburban land; micro-credit for land-poor areas; cooperation, including cooperation within the framework of international cooperation; improving business culture among farmers; stimulating economic diversification and so on.

Table 2

Patterns of land use in the agricultural sector of Ukraine*

\begin{tabular}{|l|l|}
\hline \multicolumn{1}{|c|}{ Condition } & \multicolumn{1}{c|}{ Use of land } \\
\hline Opportunities of land tenant Low provision for land & More intense \\
\hline Low quality, no demand & On their own, beyond lease \\
\hline Proximity to the city & Incomplete (part of territory) \\
\hline Increased international trade & Increased land output \\
\hline Larger share (land bank) & Increased rent \\
\hline Higher competition for the lease & More responsibilities of land tenant \\
\hline Lower provision for land & Higher land price \\
\hline Large tracts of land & Mainly for plant-growing \\
\hline Land-poor territories & Mainly for breeding \\
\hline \multicolumn{2}{|l}{ *Source: Done using the source [6]. } \\
\hline
\end{tabular}

In the global context, the problems should be resolved by the international community as well, as Ukraine will soon affect world prices to some extent, as predicted by the forecast estimates on the agricultural sector in Ukraine (according to the US Department of Agriculture (USDA), Food and Agriculture Organization (FAO) and the Organization of economic cooperation and development (OECD), in view of the tense situation with the prices for agricultural products and food on world markets. Thus, the strategy of development of agriculture and rural area in Ukraine in 2015-2020, developed by the European Union, the European bank for recon-struction and development, USAID (United States Agency for international development), the World bank and FAO (global agents), has for a key position an increase for grain production to 100 million tons per year. During the implementation of this strategy it is necessary to consider the proposed methodological principles of forming economic, social and environmental effectiveness of LM, since the total yield can be achieved either through extensive way or intense way provided for a significant increase in anthropogenic pressure on land, or changes in the structure of sown areas with increased crop and deteriorating balance of humus in the soil.

According to the strategy before 2020, it is planned to develop environmental standards and indicators of environmental problems of the agricultural sector. For the development of organic production it is suggested to develop and implement environmental legislation, harmonized with the EU legislation and create the relevant department in the Ministry of Agrarian Policy and Food of Ukraine on the development and marketing of organic production. In the agricultural management of regional administrations it is suggested to appoint at least one employee responsible for this direction. It is planned to give priority access for organic producers to tenders and to credit organic projects with interest of $4.6 \%$ in euros and $12.8 \%$ in UAH [7]. At the same time the state is trying to optimize the structure of the agricultural use of the land resources in the framework of harmonizing land-use standards with the EU; and this concerns all regions of Ukraine (Table 3). According to the forecast, there is a trend towards a significant reduction of agricultural land in all categories from $41,720.6$ thousand ha to $35,490.0$ thousand ha.

In particular, in future it is planned to restore agro-landscape balance of Ukraine before 2030 . In the national distribution of agricultural land among users up to 2030 it is planned that all categories of farms have $86.7 \%$, share in the amount and other land users $-13.3 \%$, agricultural enterprises $-39 \%$, collective farms $-10.5 \%$ individual farms $-36.6 \%$. 
ISSN 2707-5036 Bulletin of the Cherkasy University. Economic Sciences. 2019. Issue 4

Table 3

The optimal structure of agricultural use of land resources of Ukraine for 2030, thous. ha

\begin{tabular}{|l|c|c|c|c|}
\hline \multicolumn{1}{|c|}{ Indicator } & Steppe & Forest-steppe & Woodlands & Ukraine \\
\hline Total & 25019,8 & 20291,4 & 15043,6 & 60354,8 \\
\hline Agricultural land & 19159,9 & 14580,2 & 8086,4 & 41826,5 \\
\hline of this arable land & 15575,3 & 11961,6 & 6320,6 & 32857,5 \\
\hline Plow,\% & 81 & 82 & 66 & 79 \\
\hline $\begin{array}{l}\text { Arable land used for natural } \\
\text { grasslands and a forestation }\end{array}$ & 4146,8 & 3090,5 & 1392,2 & 8630,9 \\
\hline of this eroded slopes 3 ${ }^{\circ}$ or more & 1517,5 & 1715,6 & 461,0 & 3694,1 \\
\hline Unproductive lands & 1165,4 & 584,2 & 430,2 & 2179,8 \\
\hline water protection zone & 477,3 & 354,0 & 206,2 & 1037,4 \\
\hline salt & 326,4 & 37,5 & 25,6 & 389,5 \\
\hline other & 660,2 & 399,2 & 269,2 & 1328,6 \\
\hline $\begin{array}{l}\text { Arable land remains in all } \\
\text { categories }\end{array}$ & 11428,5 & 8871,1 & 3928,4 & 24227,4 \\
\hline Plow,\% & 60 & 61 & 49 & 58 \\
\hline
\end{tabular}

*Source: Done using the source [16].

These projections are impossible without improving LM system not only in quantitative but also in qualitative way, moreover, they have to fit into the current forecasts for the agribusiness of the world, including the European Union, taking into consideration the consequences for Ukraine (Table 4). According to current global forecasts up to 2020 global market volume of organic products will increase significantly and could be 200-250 billion $\$$, which will stimulate the development of organic farming in Ukraine.

Table 4

Current forecasts of agribusiness development and consequences of their implementation for LM in Ukraine*

\begin{tabular}{|l|c|c|l|}
\hline \multicolumn{1}{|c|}{ Expected factor } & Source & Timing & \multicolumn{1}{|c|}{ Consequences for Ukraine } \\
\hline $\begin{array}{l}\text { The volume of the world market } \\
\text { for organic products may be 200- } \\
250 \text { billion \$ }\end{array}$ & FAO & $\begin{array}{c}\text { before } \\
2020\end{array}$ & Development of organic farming \\
\hline Ukraine's place in world exports & $\begin{array}{c}\text { OECD } \\
\text { and } \\
\text { FAO }\end{array}$ & $\begin{array}{c}\text { before } \\
2023\end{array}$ & $\begin{array}{l}\text { Provision for } 6.3 \% \text { of world trade in wheat grain, feed } \\
\text { grain }-12.1, \text { vegetable oils - 6.0, poultry - 1.4, butter } \\
-05, \text { cheeses - 3.5\% }\end{array}$ \\
\hline $\begin{array}{l}\text { The need for grain will increase } \\
\text { by 50\% }\end{array}$ & UN & $\begin{array}{c}\text { before } \\
2030\end{array}$ & Ability to significantly influence world prices \\
\hline $\begin{array}{l}\text { The need for grain will increase } \\
\text { by } 100 \%\end{array}$ & UN & $\begin{array}{c}\text { before } \\
2050\end{array}$ & $\begin{array}{l}\text { The opportunity to significantly influence world } \\
\text { prices }\end{array}$ \\
\hline
\end{tabular}

*Source: Compiled using [2, p. 13; 3, p. 96; 5; 11, p. 35; 12; 15, p. 28]

By 2023 Ukraine will provide about $6.3 \%$ of world trade in wheat grain, feed grain -12.1 , vegetable oils -6.0 , poultry -1.4 , butter -0.5 , cheeses $-3.5 \%$. By 2050 the need for grains will increase by $100 \%$, which will significantly give the opportunity to affect world prices. If the port capacity of simultaneous storage of grain is doubled in Ukraine, logistics component of production will get cheaper; its role in international trade will be strengthened. Construction of irrigation networks and reconstruction of canals on the area of 520 thousand ha will improve the environmental, economic and social components of LM efficiency. If by 2021 grain exports from Ukraine (mainly wheat and maize) increase by $60 \%$ due to China, which, in turn, intends to significantly increase production and imports of pork, it will increase the revenues of all national agents of land interests. Biofuel production, which is projected by 2022 to grow by almost $70 \%$ (where will be used $28 \%$ of global sugar cane, $15 \%$ of vegetable oil and $12 \%$ of coarse grains) will also trigger an increase in revenues of all national agents of land interests. Worsening global problem of food security of entire regions of the world will cause the growth of prices for Ukrainian 
fertile land. Due to the introduction of new technologies in the agricultural sector, the profitability of agribusiness will increase to $75 \%$. These forecasts have a positive impact on the agricultural sector of Ukraine, again provided for the work of preventive and administrative adapters, configured primarily on the environmental component of the agricultural production.

We offer some calculations concerning the change of the crop structure in the domestic agricultural sector in the context of the implementation of the statements of presented forecast (see. Table 4). For example, the impact of replacing 1 million ha of sowing winter wheat for maize calculated in 2014 (Table 5) shows that maize being more demanded on market is capable in the current conditions to bring $610 \mathrm{UAH} / \mathrm{ha}$ more profit; that will give additional 610 million USD from 1 million hectares.

Table 5

The impact of replacing 1 million hectares of sowing winter wheat for maize (estimated in 2014)*

\begin{tabular}{|l|c|c|c|}
\hline \multicolumn{1}{|c|}{ Performance } & Winter wheat & Maize & Estimated output \\
\hline Productivity, cwt/ha & 40.1 & 61.6 & 21.5 \\
\hline Croppage, million tonnes & 4.01 & 6.16 & 2.15 \\
\hline Total cost, billion UAH & 5.86 & 8.63 & 2.77 \\
\hline Price realization, UAH / t & 1872 & 1768 & -104 \\
\hline Income, billion UAH & 7.51 & 10.89 & 3.38 \\
\hline Profit, billion UAH & 1.65 & 2.26 & 0.61 \\
\hline
\end{tabular}

*Source: Calculated on the basis [11, p. 34].

- Replacing sunflower for maize gives an opportunity to get $270 \mathrm{UAH} / \mathrm{ha}$ more profit; that represents additional 270 million USD for 1 million hectares (Table 6). Similar calculations have been made by experts of the Association "Ukrainian Agribusiness Club" for the following crops:

- Flax (oil) - for the minimum selling price of $\$ 300$. \$/t for 1 hectare income is $\$ 180 / \mathrm{ha}$;

- Technical hemp - at a minimum selling price of $\$ 890 / \mathrm{t}$ for seeds (or selling price of $\$ 70$ $\$ / t$ for fiber) profit per 1 hectare is $358 \mathrm{USD} / \mathrm{ha}$;

- Walnut - with a minimum selling price of $\$ 663 / \mathrm{t}$ on 1 hectare profit is $495 \mathrm{USD} / \mathrm{ha}$ (Agrarian business, 2015).

Table 6

The impact of replacing 1 million hectares of sowing sunflower for maize (estimated in 2014)*

\begin{tabular}{|l|c|c|c|}
\hline \multicolumn{1}{|c|}{ Performance } & Sunflower & Maize & Estimated output \\
\hline Productivity, cwt / ha & 19.4 & 61.6 & - \\
\hline Crop page, million tonnes & 1.94 & 6.16 & - \\
\hline Total cost, billion UAH & 5.47 & 8.63 & 3.16 \\
\hline Price realization, UAH / t & 3847 & 1768 & -2079 \\
\hline Income, billion UAH & 7.46 & 10.89 & 3.43 \\
\hline Profit, billion UAH & 1.99 & 2.26 & 0.27 \\
\hline
\end{tabular}

*Source: Calculated on the basis [11, p. 34].

Environmental problems in LM need to be resolved because of the inability to fit into global trends and forecasts; and considered relatively to their causes (Table 7).

Thus, the problem of the ineffectiveness of the measures for the protection of land is explained by the lack of owner's motivation to conserve depleted land. In order to solve this problem successfully, we recommend that the state should provide an equal alternative for the period of restoration of fertility (e.g. equal land area). The problem of low quality of soils is explained by irrational structure of sown areas, non-use of organic fertilizers. In the given situation we can offer:

- Development of livestock; that will ensure the inclusion of annual and perennial grasses to crop rotation;

- Green manure crops, maximum reduction of leaching organic mass from the field through 
eliminating the collection of by-products (straw), composting;

- Financial cooperation, developed under the Kyoto Protocol, which provides funding for measures designed to bind carbon in soil; that is inextricably connected with increased humus. The problem of volatility in grain prices caused by considerable dependence on external conditions for grain as raw material; can be solved through the development of domestic processing industry, livestock development.

Table 7

Causes and recommendations for solving environmental problems in LM of the agricultural sector of Ukraine*

\begin{tabular}{|c|c|c|}
\hline Problem & Causes & Recommendations for solving \\
\hline $\begin{array}{c}\text { Theffectiveness } \\
\text { of the measures } \\
\text { of land } \\
\text { protection }\end{array}$ & $\begin{array}{c}\text { Lack of owner's } \\
\text { motivation to } \\
\text { conserve depleted } \\
\text { land }\end{array}$ & $\begin{array}{r}\text { The state should provide an equal alternative for the period of } \\
\text { restoration of fertility (e.g. equal land area). }\end{array}$ \\
\hline $\begin{array}{c}\text { Low quality of } \\
\text { soils }\end{array}$ & $\begin{array}{c}\text { Irrational structure } \\
\text { of sown areas, } \\
\text { non-use of } \\
\text { organic fertilizers }\end{array}$ & $\begin{array}{c}\text { Livestock development; that will ensure the inclusion of annual and } \\
\text { perennial grasses to crop rotation; green manure crops, maximum } \\
\text { reduction of leaching organic mass from the field through eliminating } \\
\text { the collection of by-products (straw), composting; financial } \\
\text { cooperation, developed under the Kyoto Protocol, which provides } \\
\text { funding for measures designed to bind carbon in soil; that is } \\
\text { inextricably connected with increased humus. }\end{array}$ \\
\hline $\begin{array}{c}\text { Instability of } \\
\text { prices for grain }\end{array}$ & $\begin{array}{c}\text { Substantial } \\
\text { dependence on } \\
\text { external conditions } \\
\text { for grain as raw } \\
\text { material }\end{array}$ & $\begin{array}{c}\text { Development of domestic manufacturing industry, the development of } \\
\text { livestock }\end{array}$ \\
\hline
\end{tabular}

Source: Calculated based on [9, 10].

In the context of the above forecast for 2010-2014, international projects for improving LM in Ukraine have been developed and partially implemented for agricultural purposes, the main of these are:

1. Pilot project to restore irrigation systems in Ukraine (modernization of irrigation systems on Kakhovka channel) - Export-Import Bank of China, EBRD, Export-Import Bank of the United States according to tender;

2. Pilot project to restore irrigation systems in Ukraine (restoration of irrigation system in the south) - Export-Import Bank of China;

3. Project "Support to fruit and vegetable industry in the southern regions of Ukraine" Canada, Israel; China;

4. Project "Development of irrigation reclamation of Ukraine" - World Bank, Saudi Arabia,

5. Project "Support to development of Ukrainian agribusiness of small and medium size" IFC (World Bank Group);

6. Project "Agricultural energy saving and financing of small producers" - private foreign investors Corp. USA (OPIC);

7. Project "Development of granaries and agricultural cooperatives" - Dnipropetrovsk Regional Council, the Department of Foreign Affairs, Trade and Development of Canada (DFATD);

8. Project "Integrated Land Use of the Eurasian Steppes" - EU;

9. Project "Revival of navigation on the Dnieper and the Southern Bug" - "NIBULON";

10. Project "Start-up of grain technological and deep-water terminal in the port "Pivdennii" State Enterprise "Seaports administration of Ukraine" (Table 8). 
International projects for improving LM of Ukraine of agricultural purposes*

\begin{tabular}{|c|c|c|c|}
\hline Project & $\begin{array}{l}\text { Financin } \\
\mathrm{g}, \mathrm{mln} \$ \text {. }\end{array}$ & Investor & Purpose of the project \\
\hline $\begin{array}{l}\text { A pilot project to restore } \\
\text { irrigation systems in } \\
\text { Ukraine (modernization of } \\
\text { irrigation systems on } \\
\text { Kakhovka channel) }\end{array}$ & 1200 & $\begin{array}{l}\text { Export-Import Bank } \\
\text { of China, EBRD, } \\
\text { Export-Import Bank } \\
\text { of the United States } \\
\text { according to tender }\end{array}$ & $\begin{array}{l}\text { Irrigation in the area of } 250 \text { thousand ha (in } \\
\text { Kherson and Zaporizhia regions) }\end{array}$ \\
\hline $\begin{array}{l}\text { Pilot project to restore } \\
\text { irrigation systems in } \\
\text { Ukraine (restoration of } \\
\text { irrigation system in the } \\
\text { south) }\end{array}$ & 3000 & $\begin{array}{l}\text { Export-Import Bank } \\
\text { of China }\end{array}$ & $\begin{array}{c}\text { Irrigation in the area of } 1200-1400 \\
\text { thousand ha }\end{array}$ \\
\hline $\begin{array}{l}\text { Development of irrigation } \\
\text { reclamation of Ukraine }\end{array}$ & 1000 & $\begin{array}{l}\text { World Bank, Saudi } \\
\text { Arabia, China }\end{array}$ & $\begin{array}{l}\text { Development of land reclamation in all } \\
\text { regions of Ukraine }\end{array}$ \\
\hline $\begin{array}{l}\text { Agricultural energy saving } \\
\text { and financing of small } \\
\text { producers }\end{array}$ & 250 & $\begin{array}{l}\text { Private foreign } \\
\text { investors Corp. USA } \\
\text { (OPIC) }\end{array}$ & $\begin{array}{l}\text { Energy efficiency and financing of small } \\
\text { producers }\end{array}$ \\
\hline
\end{tabular}

Source: Calculated according to [4, 8].

An additional problem in the implementation of these forecasts of agribusiness development is undeveloped national joint agents. In the modern system of logistics infrastructure, in order to enter effectively the foreign market, such as grain, in Ukraine volume should be concentrated at the level of at least 1 million tons, which is possible to obtain from at least 100 thousand ha. This creates conditions for land overconcentration, as without having significant advantages in logistics software, in participation of joint agents and of the state in agricultural policy, including land relations, mini-and micro-agents are trying on their own to solve problems associated with globalization influences; and in accordance with the theory of global strains - to expand land banks and be vertically integrated. Since most private farms (mini-agents) for the quantitative measurement (land area) correspond to European standards of land use, it would be appropriate to harmonize their LM system with the European standards.

Based on this thesis, realization of investment projects in the agricultural sector shows a high probability of "domino effect", i.e. when the implementation of a project or event with possible external influence will provoke transformational staged implications without external influences. For example, let's consider two projects on the table 8. This effect is created under the action of globalization influences that form in this case consolidated unity of mini-, micro-and corporate agents.

Discussed economic priorities are the subject of this effect and in the financing of the projects pass through the following steps: clustering of small farmers, increasing their income; transition from survival level to average profit production; improving cost-effectiveness of land management; the transition from middle level to the high level of production profitability; improving the social effectiveness of land management; transition from high level to the stable high level of production profitability; improving the environmental performance of land management.

Finally, these transitions are the guarantor of harmonization of LM with the European standards.

In the process of harmonizing with European standards the three-level system of standardization should be overcome, which has developed and operates in Ukraine in recent years. In accordance with the principles of the Association Agreement with the EU, Ukraine should gradually introduce European standards (EN) as national ones. In the area of agriculture and food products, almost 300 international standards of Codex Alimentarius should be harmonized [7, p. 83]. 
An additional problem in the implementation of international projects with Ukraine is to identify country of origin, which must have certain associations. Thus, according to the action plan issued by the Ministry of Agrarian Policy and Food of Ukraine and central executive bodies whose activities are directed and coordinated by the Cabinet of Ministers of Ukraine through the Minister of Agrarian Policy and Food of Ukraine, the Program of the Cabinet of Ministers of Ukraine and the Coalition Agreement in 2015; the task number 6.29 is the creation and promotion of the brand "product of Ukraine", the content of which is drawing up and adoption of a legal act on the concept of forming a high image of Ukrainian production on the world market.

In the view of the authors, other more creative options are possible. Ukrainian farmers in their dual development (intensification and organic production) have the opportunity both to significantly increase the volume of exports of agricultural products that are in demand and meet the standards of importing countries; and consolidate the positive image of the country as a producer of organic (useful, healthy, natural) agriculture and food by forming recognizable national brand, which should be formed on analytical and consulting platform of the Association "Ukrainian club of agrarian business". Advancement of brand (e.g., similar to the «American Way» - «Amway», «Ukrainian Way» - «UkrWay») through, for example, migrant workers, Ukrainian diaspora abroad, advertising on the Ukrainian automobile, rail, water and air transport that travels abroad and high quality of products will create a positive agro-ecological image not only for a specific farming or specific national agricultural sector, but the whole country Ukraine as a food superpower. It is advisable to form national brands on the basis of wholesale markets. For example, agri-food wholesale market in Lviv «Shuvar» can introduce TM «UPway» («Ukrainian-Polish way»), which means UkrainianPolish way.

The brand is formed not only by the activities of producers, but also includes social world of consumers - mediatized world of everyday existence of people in the form of fan clubs, societies and lifestyles. Brand is what determines and mediates the relationships between people. If a brand is defined as a cultural phenomenon, whose values are carried by people, namely citizens or members of one ethnicity/ company (in the form of a friendly attitude and corporate volunteering) and consumers, it is the relationship that is distributed between them that determines the presence of the brand of the country/ company or lack thereof. Modern forms of interaction between brand and consumer are the socalled brand communities that operate in real and virtual spaces, as well as a wide range of "creativity" (from the real advertising and personalization to codesign). Therefore, it is important to create meaningful social media and to involve autonomous creativity of consumers to obtain maximum economic benefit (value) along with the spread of moral values (values). Thus, consumers can independently perform certain operations: self-service when buying goods or obtaining services through special equipment, from product selection and finishing checkout (consumer as a quasi-employee); providing consumers with information on the quality of service of their staff through various forms of monitoring and evaluation (consumer as a quasi-observer); spreading information on the company by posting comments in social media, real advertising, wearing symbols and attributes of brands (consumer as a quasi-marketing specialist).

In the conditions of integration of agricultural production of Ukraine into the world economy, the importance is growing of forming its competitive advantage through the creation of organic product sold as an ecological brand, eco-brand. Domestic researchers defineeco-brand as an intangible asset that is formed through bilateral process of value interaction (purity, healthy lifestyle) of organizations and consumers.

According to C. Koeber, agricultural producers find it important to identify and consider the value of this asset for assessing and forecasting their own economic performance. The value of ecobrand is defined as the total expenditure on the formation of semantic-symbolic component of organic agricultural products, and not as the cost of production of valuable relationships that underlie the concept of "eco-brand." Therefore, the problem is the integration of a meaningful core of brand in the methodology for assessing its value, namely identifying the sources of its formation [4; 15, pp. 207-213]. From among the latter efficient LM of the national agricultural sectorplays an 
important role.

Summarizing the study, it should be noted that the actual effectiveness of LM corresponds to $17.3 \%$ of the potential for the current state of the external and internal influence factors of environment. Comparing its level to the European average, according to the author's methodology, it can be stated that it is equal to $10 \%$ of the level of Netherlands, or $20 \%$ of the level of Germany, or $53 \%$ of the level of France (given only a partial indicator "population, which is actually fed out of 1 ha of agricultural land"). Thus in the conditions of significant threats to national defense, Ukrainian business as a completely plastic institution almost instantly (only in 2014) moved the center of gravity from metallurgy, energy and chemical industries towards the agricultural sector. With the economic and political instability, this process can be amplified through great productive motivation and globalization influences.

In economies of countries dependent on import (for agricultural products and food-stuffs) global deformation resulted in reducing immediate dependence, i.e. the formation or increase of stocks of agricultural products and food on domestic area. This will slightly reduce the range of variation of seasonal price fluctuations primarily for grain, and will also attempt to increase the amount of reserve funds, that will increase the demand of spasmodic type for food against the background of its stable growth. The possibility of Ukraine in this background to increase significantly its own production is for domestic producers the most realistic and clear globalization perspective.

We emphasize the need of diversifying agricultural production and markets, deeper processing of products that will allow to export products with greater added value and, consequently, will permit to receive its larger elements - rent, depreciation, wages, interest, profits; i.e. to motivate the appropriate agents of Land interests.

In addition, for term of globalization in Ukraine related to land use, according to the authors, is marked by the influence of LM efficiency drivers, such as: the development of logistics infrastructure; security of private land ownership and other rights to it and added value from its use; the availability of cheap funds for business; the level of monopoly; ease of doing agribusiness; the level of corruption; the system of state quality standards; the development of public-private partnerships; decentralization of power; the system of state protectionism. These drivers, depending on the specific situation, may change places with each other, in other words they are mobile. The list of drivers is also temporary, e.g. the possibility exists of the appearance of new drivers or elimination of their effect due to the loss of sensitivity of land users on their change.

Regarding preventive and administrative adapters, today one of the largest of these is the moratorium on sale of agricultural land. The country's scope represents the general economic conditions, registered in the Commercial and Land Codes, as well as taxation, provisions of the Law of Ukraine "About Foreign Economic Activity" non-restriction of land banks, forming vertically integrated structures. Globalization prospects of national land users under the action of these drivers, preventive and administrative adapter with peculiarities enabled by the country's scope, are forming position of land users in the international system of division of labor, which ultimately determines the level of LM perspective.

The perspective level of land use should be considered in the process of harmonization of national LM of the agricultural sector of globalization prospects for sustainable development and food security. According to the authors, this process can be represented as a scheme of harmonization of economic interests of actors of land relations through financial and organizational capacities of these actors. The logic of the scheme is explained by the fact that the basis of actions of LM are economic interests of mini-agents, micro-agents, joint agents, the state, regional and global agents, which are oriented on a certain amount (share amount) of owning, using and handling objects of management (land, land rights or the added value from land-use), taking into account possible level of globalization impacts (social, economic, political, organizational, financial, information). Thus, a dynamic level of efficiency of LM is formed, as well as its tendency, to be perceived by agents of land interests as input for the new cycle of activity (operational, tactical or 
strategic planning).

Conclusions. As a result, we should note that the basic global trends and their impact on LM of the agricultural sector of Ukraine are reduced mainly to increased anthropogenic load on them. The author scheme of "domino effect" from the implementation of investment processes in agriculture, towards harmonization of LM with the European standards. We suggest creation of a network structure of organic products under the trademark «UkrWay» for analytical and advisory platform of Ukrainian club of agrarian business. We develop the scheme of harmonizing economic interests of land relations actors through of their capabilities. We design the scheme of forming perspective level of LM through globalization perspectives and internal drivers.

\section{References (in language original)}

1. Алескерова Ю. В. Моделі страхової політики при сільськогосподарському страхуванні. Економіка АПК. 2014. № 10. С. 45-53.

2. Андрійчук В. Г. Виклики агробізнесу: пошук відповідей. Економіка АПК. 2015. № 5. С. 12 22.

3. Артиш В. І. Виробництво органічної продукції в країнах Європейського Союзу. Економіка АПК. 2014. № 2. С. 93-96.

4. Брагинець М. В., Зось-Кіор М. В., Співак С. М., Бучнєв М. М., Васюренко Л. В., Нігматова О.С. Брендінг як ринковий механізм створення конкурентної переваги суб'єктів малого бізнесу України. Менеджмент у XXI сторіччі: методологія і практика : монографія. / під ред. проф. I. А. Маркіної. Полтава : ПолтНТУ, 2015. 346 с.

5. Голян В. Институциональные разрывы земельной реформы в Украине. Економіст. 2012. № 3. C. 7-11.

6. Дієсперов В. С. Використання земельних ресурсів сільських територій. Економіка АПК. 2014. № 11. С. $48-56$.

7. Зінчук Т. О. Проблеми адаптації аграрного сектору економіки до умов. Угоди про зону вільної торгівлі Україна-СС. Економіка АПК. 2015. № 5. С. 79-87.

8. Кириленко I. Г., Дем'янчук В. В. Перспективи вітчизняного АПК в світлі прогнозів світового ринку продовольства. Економіка АПК. 2015. № 1. С. 21-28.

9. Лупенко Ю. О., Месель-Веселяк В. Я. Стратегічні напрями розвитку сільського господарства України на період до 2020 року. Київ : ННЦ «IAE», 2012. 218 с.

10. Марков Р. В. Виробництво зерна: конкурентноздатність в обмін на родючість грунтів. Збірник наукових прачь Харківського наиіонального аграрного університету імені В. В. Докучаєва. Серія «Економіка АПК і природокористування». Харків : ХНАУ, 2009. № 12. С. 341-351.

11. Петриченко В. Ф., Безуглий М. Д., Жук В. М., Іващенко О. О. Нова стратегія виробництва зернових та олійних культур в Україні. Київ : Аграр. наука, 2012. 48 с.

12. Ромащенко М. І. Концептуальні засади відновлення зрошення у південному регіоні України. Меліорачія і водне господарство. 2013. Вип. 100. Т. 1. С. 7-17.

13. Шубравська О. В. Агропродовольчий розвиток України в контексті глобальних викликів. Економіка АПК. 2014. № 7. С. 52-58.

14. Bilan Y., Zos-Kior M., Nitsenko V., Sinelnikau U., Ilin V. Projecting the social component of the efficient management of land resources. Journal of Security and Sustainability Issues. 2017. № 7(2). P. 287300 .

15. Koeber C. Consumptive labor: the increasing importance of consumers in the labor process. Humanity \& Society. 2011. Vol 35, № 3. P. 205-232.

16. Zos-Kior M., Kuksa I., Ilyin V., Chaikina A. Land management prospects. Economic Annals-XXI. №9-10. 2016. P. 243-246.

\section{References}

1. Alaskerova Y. V. (2014). Models of insurance policy in agricultural insurance. Ekonomika APK [Economy of the AIC], 10, 45-53.

2. Andriychuk V.G. (2015). Challenges for agribusiness: the search for answers. Ekonomika APK [Economy of the AIC], 5, 12-22.

3. Artish V.I. (2014). Production of organic products in the countries of the European Union. Ekonomika APK [Economy of the AIC], 2, 93-96. 
4. Braginets M., Zos-Kior M., Spivak E., Buchnev M., Vasyurenko L., Nigmatova O. (2015). Brendinh yak rynkovyi mekhanizm stvorennia konkurentnoi perevahy subiektiv maloho biznesu Ukrainy. Menedzhment u KhKhI storichchi: metodolohiia i praktyka [Management in the 21st Century: Methodology and Practice]. Poltava: PoltNTU. 346 (in. Ukr.). $3,7-11$.

5. Golyan V. (2012). Institutional Displacements of Land Reform in Ukraine. Economist [Economist],

6. Diesperov V.S. (2014). Use of Land Resources of Rural Territories. Ekonomika APK [Economy of the AIC], 11, 48-56.

7. Zinchuk T.O. (2015). Problems of adaptation of the agrarian sector of economy to the conditions. Ukraine-EU Free Trade Agreement. Ekonomika APK [Economy of the AIC], 5, 79-87.

8. Kirilenko I.G. (2015). Prospects of the domestic agroindustrial complex in the light of the forecasts of the world food market. Ekonomika APK [Economy of the AIC], 1, 21-28.

9. Lupenko Yu.O., Mesel-Veselyak V.Y. et al. (2012). Stratehichni napriamy rozvytku silskoho hospodarstva Ukrainy na period do 2020 roku [Strategic directions of development of agriculture of Ukraine for the period up to 2020]. Kyiv: NSC "IAE". 218 (in. Ukr.).

10. Markov R.V. (2009). Production of grain: competitiveness in exchange for soil fertility. Zbirnyk naukovykh prats Kharkivskoho natsionalnoho ahrarnoho universytetu imeni V. V. Dokuchaieva. Seriia "Ekonomika APK i pryrodokorystuvannia» [Collection of scientific works of the Kharkiv National Agricultural University named after V.V. Dokuchaev. Series "Economics of agroindustrial complex and nature management"], 12, 341-351.

11. Petrichenko V.F, Bezugly M.D., Zhuk V.M., Ivashchenko O. O. (2012). Nova stratehiia vyrobnytstva zernovykh ta oliinykh kultur $v$ Ukraini [A new strategy for the production of cereals and oilseeds in Ukraine]. Kyiv: Agrarian Science. 48 (in. Ukr.).

12. Romashchenko M.I. (2013). Conceptual Principles of Irrigation Restoration in the Southern Region of Ukraine. Melioratsiia i vodne hospodarstvo [Reclamation and Water Management], 100, 7-17.

13. Shubravska O. (2014). Agrofood Development of Ukraine in the Context of Global Challenges. Ekonomika APK [Economy of the AIC], 7, 52-58.

14. Bilan Y., Zos-Kior M., Nitsenko V., Sinelnikau U., Ilin V. (2017). Projecting the social component of the efficient management of land resources. Journal of Security and Sustainability Issues, 7(2), 287-300.

15. Koeber C. (2011). Consumptive labor: the increasing importance of consumers in the labor process. Humanity \& Society, 35(3), 205-232.

16. Zos-Kior M., Kuksa I., Ilyin V., Chaikina A. (2016). Land management prospects. Economic Annals-XXI, 9-10, 243-246.

\section{ЗОСБ-КІОР Микола Валерійович}

д.е.н., доцент,

професор кафедри менеджменту,

Полтавська державна аграрна академія,

м. Полтава, Україна

\section{ОВЧАРЕНКО Свген Іванович}

д.е.н., професор,

завідувач кафедри публічного управління,

менеджменту та маркетингу,

Східноукраїнський національний університет імені

Володимира Даля,

м. Сєвєродонецьк, Україна

\section{АРБУЗОВА Тетяна Василівна}

к.е.н., доцент,

доцент кафедри публічного управління,

адміністрування та міжнародної економіки, 
Білоцерківський національний аграрний університет,

м. Біла Церква, Україна

\section{СТАЛИЙ РОЗВИТОК, ДЕЦЕНТРАЛІЗАЦІЯ ТА ГАРМОНІЗАЦІЯ В УПРАВЛІННІ ЗЕМЕЛЬНИМИ РЕСУРСАМИ АГРАРНОГО СЕКТОРА}

Проблема. Дослідження прогнозування економічної, сочіальної, екологічної та інтегральної ефективності управління земельними ресурсами аграрного сектора дозволяють формалізовано здійснити перехід на передові світові аналоги землекористування. При иьому держсава має діяти доступними інструментами, враховуючи не тільки економічні закони, а й ті тендениї $i$ закономірності, які склалися на рівні світових аграрних, у тому числі земельних відносин. Еволючія прочесів із обмеженою передбачуваністю потребус певної мети і контексту, який вбачається в гармонізачії ефективності управління земельними ресурсами аграрного сектора із глобалізачійними перспективами, враховуючи прочеси децентралізачії та необхідність сталого розвитку. Цей контекст обумовлює логіку иієї статті.

Метою статті є дослідження сталого розвитку, децентралізації та гармонізачії в управлінні земельними ресурсами аграрного сектора.

Результати. В рамках сталого розвитку сільських територій, деџентралізації та гармонізачії в периу чергу з європейськими стандартами розглянуто можливості управління земельними ресурсами. Визначено основні світові тендениї та їх вплив на управління земельними ресурсами аграрного сектора економіки Украйни, що зводиться переважно до зростання антропогенного навантаження на них. Розглянуто закономірності національного землекористування та ті проблеми, що вони породжують. 3 урахуванням тенденцій $i$ виявлених закономірностей було визначено сучасні прогнози розвитку аграрного бізнесу та наслідки їх реалізаиії в управлінні земельними ресурсами в Украйні.

Наукова новизна. Новизна підходу полягає у формування перспективного рівня управління земельними ресурсами через глобалізачійні перспективи та внутрішні драйвери, які враховують економічні інтереси суб'єктів управління земельними ресурсами, орієнтованих на певну величину володіння, розпорядження та користування об'єктами управління, $i$ можливий рівень глобалізаційних впливів, щуо дає змогу гармонізувати інтереси иих суб'єктів через можливості дечентралізачії та реалізачію проектів зі сталого розвитку.

Висновки. Запропонована авторська схема «ефекту доміно» від реалізачї інвестичійних прочесів у землеробстві до гармонізачії управління земельними ресурсами із загальноєвропейськими стандартами. Запропоновано створення мережевої структури органічної продукиї під TM «UkrWay» на аналітико-консультачійній платформі Асочіачії «Український клуб аграрного бізнесу», що дозволяє оперативно діагностувати попит за рахунок споживача як квазі-прачівника, квазіспостерігача та квазі-маркетолога й відповідно застосовувати динамічні системи управління земельними ресурсами аграрного сектора економіки. Розроблено схему гармонізації економічних інтересів суб'єктів управління земельними ресурсами в умовах дечентралізачії через їх фінансовоорганізачійні можливості задля орієнтачії на володіння, розпорядження та користування об'єктами управління.

Ключові слова: аграрний сектор, сталий розвиток, гармонізачія, управління земельними ресурсами, децентралізачія. 